\title{
Social Capital and Community Heterogeneity
}

\author{
Hilde Coffé
}

Accepted: 27 May 2008/Published online: 1 July 2008

(C) The Author(s) 2008

\begin{abstract}
Recent findings indicate that more pronounced community heterogeneity is associated with lower levels of social capital. These studies, however, concentrate on specific aspects in which people differ (such as income inequality or ethnic diversity). In the present paper, we introduce the number of parties in the local party system as a more encompassing measure of community heterogeneity. This builds on the argument that the number of relevant socio-economic cleavages in the population (i.e. heterogeneity) determines the level of party system fragmentation. Using data on 307 Flemish municipalities, we find that municipalities with a more heterogeneous population indeed have lower levels of social capital. Hence, our study endorses-and generalizes-previous results linking community heterogeneity to lower levels of social capital.
\end{abstract}

Keywords Social capital · Community heterogeneity $\cdot$ Cleavage structure

\section{Introduction}

In recent years, social capital has been designated as a constructive force that leads to improved performance on a vast array of political, social and economic phenomena (for a review, see Halpern 2005). Though this interpretation of social capital as a normatively positive thing has attracted severe criticism (see e.g. Foley and Edwards 1998; DeFilippis 2001; Casey 2004), it deserves credit for raising the question why some regions have higher levels of social capital than others. This question is important irrespective of the fact whether social capital is good or bad as it provides some insight into how we can affect its development. ${ }^{1}$ One of the (partial) answers to this question links community heterogeneity to social capital formation. Social capital formation, so the argument goes, is more difficult in

\footnotetext{
${ }^{1}$ Note that a given level of social capital may in itself be insufficient to bring about certain (un)desired outcomes. Indeed, the political and/or institutional setting may affect the efficacy of social capital (e.g. Maloney et al. 2000).
}

H. Coffé $(\bowtie)$

Utrecht University, Utrecht, The Netherlands

e-mail: h.r.coffe@uu.nl 
very heterogeneous communities (Alesina and La Ferrara 2000). Empirical analyses of this hypothesis have, however, focused on specific measures of heterogeneity such as income inequality (e.g. Stolle 2000) or ethnic diversity (Knack and Keefer 1997; Delhey and Newton 2005). In the present paper, we extend these previous analyses in two important ways.

Firstly, we introduce a more encompassing measure of heterogeneity, namely the number of parties in the local party system. This builds on the argument that the level of party system fragmentation is dependent on the number of socio-economic cleavages in the electorate (Lipset and Rokkan 1967; Karvonen and Kuhnle 2002). The number of parties required to express all dimensions of diversity in a society is higher when the amount of cleavage dimensions increases (Lijphart 1999), such that higher party system fragmentation points to more extensive community heterogeneity. This approach allows us to assess whether previously obtained results can be generalized through the use of a more encompassing measure of heterogeneity.

Secondly, we evaluate the relation between social capital and heterogeneity at a lower level of government by looking at aggregate-level social capital in 307 Flemish municipalities. Data on the local government level have been largely overlooked thus far. Nonetheless, it allows for the compilation of a much larger dataset and, importantly, implies a more stringent test of the central hypotheses because the variation in social capital is likely to be weaker across municipalities than across countries or regions (Rice 2001).

The remainder of the paper is structured as follows. A brief description of the social capital concept and its relation with community heterogeneity are given in the first part. This section also reviews prior empirical results. The next section addresses our own analysis. Prior to the presentation of our results, we bring forward our indicators of social capital and community heterogeneity along with the particularities of the model and the estimation methodology. The last section concludes.

\section{Social Capital and Community Heterogeneity}

\subsection{The Community Heterogeneity Thesis}

Despite considerable disagreement concerning the very definition of social capital, most scholars recognize three core components: generalized trust, norms of reciprocity and networks. Social capital is therefore understood as both a structural phenomenon (social networks) and a cultural or attitudinal phenomenon (social norms and trust) (Hooghe and Stolle 2003). Moreover, it is often regarded as an aggregate concept, a characteristic of communities (Putnam 1993; Newton 2001). It is a societal resource that links citizens to each other and enables them to pursue their common objectives more effectively (whether or not these goals are socially desirable outcomes). The resulting influence of social capital on various social, economic and political phenomena naturally provokes the question what factors promote (or block) its emergence. Thus far, various explanations have been offered. Putnam (1993), for example, gives historical factors a principal role. In his view, the higher level of social capital in the northern parts of Italy can be traced back to the emergence of self-government in the northern cities at a time (i.e. the late Middle Ages) when the southern regions still suffered under the rule of Norman mercenaries. Others have emphasized the level of economic development of a country (Stolle 2000), the existing political institutions (Freitag 2006) or the design of welfare state policies (Kumlin and Rothstein 2005).

The influence of the community heterogeneity on social capital formation has also featured prominently in the literature. The hypothesis is that social capital is likely to be 
weaker in heterogeneous communities because people have more trust in and feel more comfortable interacting with others who are similar to themselves, for example in terms of race and ethnicity (Knack and Keefer 1997; Alesina and La Ferrara 2000). The argument refers to the presence of an us versus them way of thinking in which groups are likely to develop strong social connections and levels of generalized trust among its members (i.e. 'bonding' social capital), but generally tend to distinguish themselves from other groupsor even positively avoid or distrust members from these other groups (i.e. lacking 'bridging' social capital) (Portes 1998; Abrams et al. 2005).

One possible reason for the emergence of us versus them thinking is that people might feel threatened by other groups in a struggle over governmental resources or for (cultural) dominance (Boix and Posner 1998; Stolle 2000; Leigh 2006a). This argument underlies the threat hypothesis, which states that in communities with a high presence of immigrants, autochthons have more prejudices (Blalock 1967; Oliver and Mendelberg 2001). However, minority groups may also feel threatened if they fear discrimination (Costa and Kahn 2003). The basic idea is that each group in a polarized society is concerned mainly with its own interests at the expense of socially optimal behaviour. This 'struggle over government resources'-argument is in line with micro-economic theories assuming that governments are predominantly engaged in redistributive activities and that different groups will dispute the distribution of these resources (e.g. Meltzer and Richard 1981).

Another reason for us versus them behaviour is that individuals from different groups are less likely to share common backgrounds and to have similar values and norms (Rothstein and Uslaner 2004). This makes it harder to 'predict' the behaviour of others (Hardin 1993; Misztal 1995), which increases the hurdle to trust each other and make selfenforcing agreements.

Note finally that, although the argument has particularly been presented in terms of ethnic or racial divisions in the population, it can be generalized to other differences among groups in the population, like differences in income, religion, language, local identity.

\subsection{Exploring the Empirical Literature}

Empirical research on the association between community heterogeneity and the level of social capital has been conducted using both data at the individual (micro) level and the social (macro) level.

The individual-level studies mostly use a multilevel approach. They explain an individual's investment in social capital by regarding both the individual's socio-economic characteristics and the social context in which (s)he is embedded. The results demonstrate that social capital formation is significantly lower in ethnically or economically heterogeneous communities (Sampson et al. 1997; Alesina and La Ferrara 2000; Leigh 2006b). The population's age distribution is insignificantly, though generally negatively, correlated with the level of social capital (Alesina and La Ferrara 2000). Leigh (2006a) shows that when different measures for fractionalisation are included in the same model (i.e. income, ethnicity, religion and language), only income inequality is significantly negatively associated with trust. Costa and Kahn (2003) support these results in a model restricted to contextual variables. They find that volunteering, voluntary association membership and trust among 25- to 54-year-old are lower in heterogeneous communities. The effect is particularly strong for wage inequality.

Experimental research confirms above-mentioned conclusions. For example, Glaeser et al. (2000) analyse the behaviour of Harvard undergraduates in a two-person trust game. 
The results indicate that subjects from different races or nationalities behave in a less trustworthy manner towards one another compared to couples where both subjects have the same race or nationality. Racial diversity within groups thus appears to restrict trust in others and the reliability of someone's behaviour towards others.

Studies at the macro-level have concentrated strongly on the variation in social capital across countries. Rothstein and Stolle (2001) and Rothstein and Uslaner (2004), for example, find that higher income inequality is associated with lower levels of trust. Delhey and Newton (2005), in a comparative study on social trust in 60 countries, confirm this finding and also show that countries with high levels of trust are characterised by ethnic homogeneity (a results previously reported in Knack and Keefer 1997). A study of 40 countries by La Porta et al. (1997) finds a similar negative relation between ethno-linguistic heterogeneity and social capital.

Finally, a few studies have regarded the link between community heterogeneity and social capital at a lower level of government. Hero (1998; 2003) looks at Putnam's (1993) index of social capital in 48 American States and finds it to be strongly and negatively associated with the percentage of individuals form African, South-American or Asian origin. Coffé and Geys' (2006) analysis of social capital data in Flemish municipalities supports the hypothesis that community heterogeneity (measured by the number of different nationalities in the population) is significantly negatively related to social capital. Income inequality, however, does not have a significant effect. Putnam (2007) concludes in his recent study on diversity and community that in ethnically diverse neighbourhoods trust tends to be lower, friends fewer and community cooperation rarer.

\section{Analysis}

\subsection{Measuring Social Capital}

Since social capital is embedded in and realized through people's social relations (see Bourdieux 1985; Coleman 1988), it is appropriate to understand it as an aggregate concept. Hence, we operationalise social capital at the community level (rather than the individual level). Specifically, we include three indicators to measure the level of social capital in the Flemish municipalities. Lacking survey-based data at the municipal level in Flanders, all three are macro-indicators.

Our first indicator measures the extent of associational life in the municipality. Voluntary associations are often argued to be a driving force behind the creation of social capital because of their socialization effects on democratic and cooperative values and norms. Moreover, the trust and norms of (indirect) reciprocity that people generate in associations are spread over the whole community, encompassing citizens that are not equally active in associational life (Stolle 2000). We use the number of a wide variety of organizations (per capita) in each municipality to measure the density of associational activity (Lauwerysen and Colpaert 2004; Bloso 2004). These include sports clubs, neighbourhood committees, fan clubs, hobby clubs and local branches of (inter)national associations for among others women, retired people and civil rights movements. Clearly, some of these groups are more 'bonding' or 'bridging' than others. Yet, while it has been argued that the latter type of organizations are better for the formation of social capital than the former (e.g. Gittell and Vidal 1998; Marshall and Stolle 2004), our measure includes all available associations. It thus provides a view on associational activity within Flemish municipalities that is quite encompassing. 
Note that we lack data on informal contacts people may have. Still, though loose and amorphous networks of individuals might also facilitate civic attitudes and behaviours, the broadening of the social capital concept to include various types of social interaction might constitute a conceptual problem as it becomes fuzzier and its relationship to performance less obvious (Stolle 2003). Besides, Stolle (1998) argues that informal socializing is not particularly conducive to social capital. Unfortunately, we also lack information on the membership rates of the different associations. Hence, we are constrained by our data to follow the prevailing literature (e.g. Rice and Sumberg 1997; Maloney et al. 2000) and focus only on the number of associations. A dense network of voluntary associations refers to a high level of social capital.

Following recent work by Putnam (2000), Costa and Kahn (2003) and Casey (2004), we use electoral turnout in the 2000 municipal elections as a second indicator of social capital. This is measured as the number of votes cast on Election Day divided by the number of registered voters. Given that the probability of affecting the election outcome is small in most elections, turning out to cast a vote is likely to be driven by feelings of 'civic duty' or signals an individual's engagement toward the 'common good' (Riker and Ordeshook 1968; Overbye 1995). Importantly, voting is compulsory in Belgium. Still, penalisation of non-voters is virtually non-existent in practice. Only about $0.06 \%$ of the 628,957 nonvoters during the 2000 municipal elections were prosecuted (Geys 2004). Moreover, turnout rates show significant variation between the Flemish municipalities (ranging from $87.95 \%$ to $98.46 \%$ in the election under study). Both these elements allow us to interpret higher turnout levels as signalling higher civic involvement among the population (and thus a higher level of social capital). The extent of associational life and electoral turnout are indicators that cover the structural component of social capital.

Social norms, and in particular generalized trust, establish the cultural aspects of social capital (Putnam 1993; Inglehart 1997). Though this choice has recently been criticized by Glaeser et al. (2000), most previous studies rely on attitudinal survey questions (such as from the World Values Studies) to measure the level of trust in a region. Such data are, unfortunately, not available at the local level in Flanders. Hence, we rely on objective crime rates-which include all criminal facts committed within the boundaries of a municipality - to measure subjective feelings of trust (see also Rice and Sumberg 1997). While this is clearly not ideal, several arguments support this choice. Firstly, the level of criminal activity is related to regional and national variations in underlying norms (Halpern 2005). Higher crime is more likely in areas where norms and values are more lenient towards such activities. Secondly, Delhey and Newton (2004) show that distrust accompanies conflict. The extent to which citizens are confronted with criminal behaviour within their municipality affects their image of the dominant norms and values in their environment, the extent to which their fellow-citizens adhere to these and thereby their mutual trust. High conflict areas are therefore likely to be characterized by higher levels of distrust. Hence, as crime in societies will lower citizens' respect and trust in one another, low crime rates are expected to be indicative of a high level of social capital.

These three indicators are expected to tap into one underlying concept (i.e. social capital). Hence, we combine them into a single component using Principle Component Analysis (PCA). ${ }^{2}$ This procedure mitigates the influence of idiosyncratic measurement

\footnotetext{
${ }^{2}$ The Keiser-Meyer-Olkin (KMO) measure of sampling adequacy and the Bartlett test of sphericity both indicate the suitability of our data for PCA. KMO equals 0.55 and is above the critical value of 0.50 . The Bartlett test of sphericity significantly rejects the null hypothesis that the intercorrelation matrix comes from a population in which the variables are non-collinear $\left(\chi^{2}(3)=100.89 ; p<0.001\right)$.
} 
Table 1 The social capital component

\begin{tabular}{lc}
\hline Component measure & Component loading \\
\hline Electoral turnout & 0.84 \\
Crime rate & -0.75 \\
Associational life & 0.60
\end{tabular}

Eigenvalue: 1,62

Percentage variance: 54,08

error within each of the variables and maximizes the probability of measuring the underlying concept more precisely. Thus, even though the individual indicators are arguably less than ideal and their choice might be criticized, the index retrieved from the PCA "probably measures social capital better than any single indicator" (Bjørnskov 2003, p. 7; see also Rice and Sumberg 1997; Knack 2002). The results of the PCA are summarized in Table 1 . It is clear that all three indicators load powerfully onto one underlying component extracted from the data. ${ }^{3}$

\subsection{Measuring Community Heterogeneity}

Where the focus of previous studies has predominantly been on income and ethnic diversity, we introduce the level of party system fragmentation as a (more general) proxy of community heterogeneity. This builds on the argument that party system fragmentation is a direct function of the number of socio-economic cleavages in the electorate (Lipset and Rokkan 1967; Karvonen and Kuhnle 2002). These cleavages can be seen as demarcation lines that run through the population and by which this population can be divided into separate groups (e.g. rich/poor, religious/secular). They thus tap into various sources of heterogeneity within the population. Importantly, the number of parties required to express all dimensions of political conflict in a society is higher when the amount of conflicting cleavage dimensions increases (Lijphart 1999). Taagepera and Grofman (1985) and Taagepera and Shugart (1989) even claim the existence of a mathematical relation between both variables, stating that the number of parties equals the number of politically relevant issue (or cleavage) dimensions plus one.

This relation between socio-economic heterogeneity and party system fragmentation is supported in empirical research by, amongst others, Rae and Taylor (1970), Lane and Ersson (1987) and Jones (1997). Importantly, Geys (2006) shows that this is also the case in a Belgian setting and at the local government level over the period 1982-2000. Indeed, his results indicate that the number of parties in the Belgian municipal elections is significantly positively affected by all four heterogeneity measures included in the model: i.e. income inequality, the number of different nationalities in the municipality, linguistic heterogeneity and the number of pre-1977 municipalities that constitute the current municipality (which is representative of the large-scale municipal amalgamation operation in Belgium in 1976).

\footnotetext{
3 In line with the main strand of the literature, our social capital index takes account of the dual nature of the concept by comprising both structural aspects (associational life and political involvement) and a cultural aspect (trust). We should note, however, that some authors caution against merging indicators of social connectedness with indicators of generalized trust and reciprocity (Knack and Keefer 1997; Newton 1999; Knack 2002).
} 
Following the above line of argument and supported by the findings of (Geys 2006), we introduce the number of parties competing in municipal elections as a general proxy for community heterogeneity in the Flemish municipalities. We operationalise this through a simple count of the number of parties that obtained at least one vote in the 1994 municipal elections. On average, about 5.5 parties participated in each municipality, with a minimum of two and a maximum of 18 parties. We prefer this actual number of parties to the effective number of parties. ${ }^{4}$ The reason is that-prior to the elections-the relevant decision is to form a political party and enter the electoral competition. This is a priori unrelated to the share of the votes this party obtains in those elections (for a similar discussion, see Ordeshook and Shvetsova 1994; Geys 2006). Nonetheless, it could be argued that the electoral result of each party gives an indication of the relative size of the various groups within the municipality. This may matter for their behaviour towards one another (see the threat hypothesis). Hence, for comparison, we also estimate the model with the effective number of parties as our central explanatory variable. The Flemish municipalities had 3.46 effective parties on average in the election of 1994, with a minimum and maximum of 1.45 and 7.94 parties respectively. The actual and effective number of parties are strongly correlated $(r=0.78)$.

Obviously, the number of parties competing in the election is also influenced by the characteristics of the electoral system. More proportional systems lower the hurdle for small groups to form a party and run for office (Duverger 1954; Sartori 1968). Fortunately, all Belgian municipalities use the same proportional electoral system (i.e. highest average Imperiali-without legal thresholds) to (s)elect the composition of the local council (the legislative power in the municipality). Still, the district magnitude (i.e. the number of seats in the local council) does differ across municipalities and ranges from seven seats in the smallest municipalities (Herstappe and Mesen) up to 55 seats in the largest municipality (Antwerp). As the number of legislative seats allocated affects the proportionality of the electoral system (Sartori 1968), this might mitigate the suitability of the number of parties as a measure of heterogeneity in our setting. We return more extensively to the possible implications of this relation on our findings when discussing our empirical results.

\subsection{Empirical Model}

While estimating the relation between community heterogeneity $\left(\mathrm{HET}_{\mathrm{i}}\right)$ and social capital $\left(\mathrm{SOCKAP}_{\mathrm{i}}\right)$, it is important to control for rival explanations. Hence, we introduce a number of socio-economic control variables based on the findings in earlier research. Specifically, we estimate the following empirical model using data on 307 Flemish municipalities (one municipality, Herstappe, is excluded due to missing data):

$$
\begin{aligned}
\text { SOCKAP }_{i}= & a+b_{1} \text { INC }_{i}+b_{2} \text { EDUC }_{i}+b_{3} \text { UNEM }_{i}+b_{4} \text { AGE }_{i}+b_{5} \ln \left(\text { POP }_{i}\right) \\
& +b_{6} \text { CONC }_{i}+b_{7} \text { MIGR }_{i}+b_{8} \text { HOME }_{i}+b_{9} \text { HET }_{i}+e_{i}
\end{aligned}
$$

A first socio-demographic control variable is the per capita taxable income (in 1000 Euro) $\left(\mathrm{INC}_{\mathrm{i}}\right)$. Secondly, we include the level of education within a community $\left(\mathrm{EDUC}_{\mathrm{i}}\right)$, measured by the percentage of the population (older than 20 years) with a college or university degree. A third control variable is the unemployment rate $\left(\mathrm{UNEM}_{\mathrm{i}}\right)$, defined as the

\footnotetext{
${ }_{4}^{4}$ The latter takes into account the relative size of each party and is measured as: $1 / \sum_{i=1}^{n} p_{i}^{2}$, with $n$ equal to the number of parties and $p_{i}$ the vote share of party $i$ (Laakso and Taagepera 1979).
} 
percentage of the total municipal population that is unemployed. The fourth variable is the share of elderly (over age 65 ) within a community $\left(\mathrm{AGE}_{\mathrm{i}}\right) .^{5}$

Further, to control for the anonymity and alienation that are characteristic of large cities (Wirth 1938; Weber 1947) and the fact that large numbers tend to weaken the force of ethical rules (Buchanan 1965), we include population size and population density. Population size $\left(\mathrm{POP}_{\mathrm{i}}\right)$ equals the number of inhabitants in the municipality (the natural logarithm controls for the highly skewed distribution of this variable). Population density $\left(\mathrm{CONC}_{\mathrm{i}}\right)$ is measured by the number of inhabitants per square kilometre. Additionally, we control for the (lack of) mobility in the municipal population using the in- and outward migration in the municipality during 1 year as a percentage of the total population $\left(\mathrm{MIGR}_{\mathrm{i}}\right)$. We expect mobility to reduce social capital as "leaving a community tends to destroy established bonds, thus depriving family and children of a major source of social capital" (Portes 1998, p. 11; Bowles and Gintis 2002). Finally, we add the extent of homeownership $\left(\mathrm{HOME}_{\mathrm{i}}\right)$. Homeownership does not only imply that one is likely to stay longer in a region (thus reducing population mobility), but also entails a financial investment in a certain environment. As the quality of the (social) environment influences housing prices, homeownership creates an additional incentive to invest in social capital (Green and White 1997; DiPasquale and Glaeser 1999). Homeownership is measured by the percentage of owner-occupiers. Descriptive statistics for all variables are provided in the Appendix.

\subsection{Empirical Results}

Our findings are presented in Table 2. Columns (1) to (4) present results using the actual number of parties as our proxy for heterogeneity, whereas columns (5) to (8) use the effective number of parties. In both cases, results in even-numbered columns are obtained by removing the non-significant variables one by one from the model to obtain a more efficient estimation. Prior to discussing the results, two methodological issues must be raised. Firstly, we employ two different estimation techniques. Columns (1), (2), (5) and (6) present the results using OLS. However, as OLS does not control for the limited range of values that our dependent variable takes, this could lead to biased estimation results and incorrect inferences (Thomas 1997). Hence, in columns (3), (4), (7) and (8) we report results using an interval regression technique where we impose that the dependent variable is limited to a given interval. Mathematically, this is equivalent to performing a Tobitestimation while imposing both a top and bottom boundary. It is clear from Table 2 that the results from both estimations are very similar.

Secondly, we should mention that the direction of causality is not unambiguous for most of the variables included in the model. For example, higher education levels may lead to higher investment in social capital (Verba et al. 1995), but is has also been argued that social capital has a positive effect on school results (La Porta et al. 1997). To minimize the problems associated with this reverse causality, we operationalize each of our explanatory variables one year prior to the measurement of social capital (i.e. using data from 1999). ${ }^{6}$

\footnotetext{
5 Inferences about individuals based on aggregate level data are prone to the ecological fallacy. However, we only introduce these variables as controls in the model and make no claim as to individual level behaviour in Flemish municipalities. Yet, we do confer how our results relate to individual level findings in the literature.

${ }^{6}$ Exceptions to this rule are the education level and homeownership. For both these variables, we use data from 1991 (due to availability). Also, as mentioned previously, we employ data on the number of parties in the 1994 municipal elections (the most recent municipal election prior to 2000).
} 


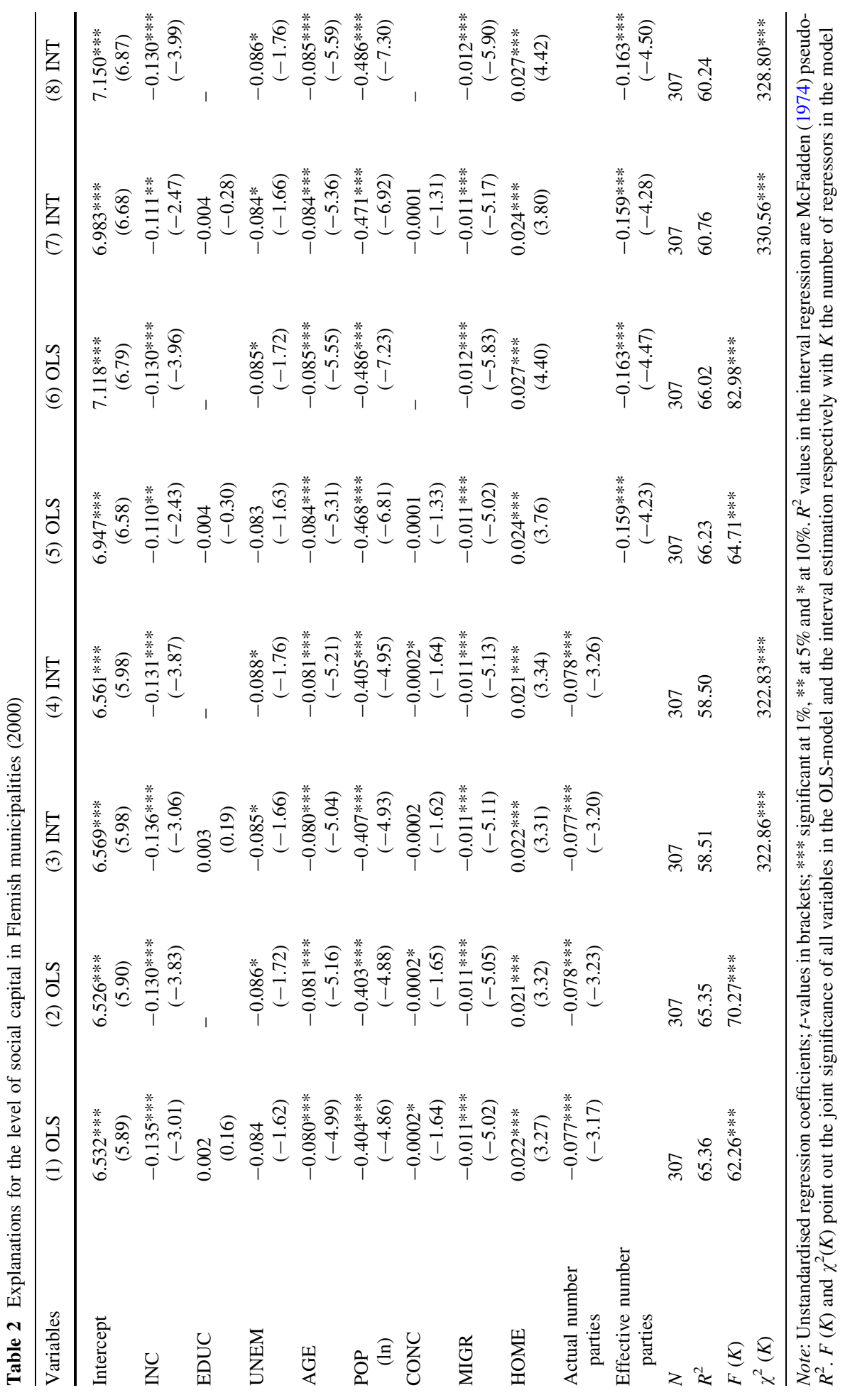


However, since the variation of our variables over time is only limited, this obviously does not resolve all problems of causality. As such, we-by way of precaution-make no statements regarding the causality of the found effects and rather talk about a mutual relation or correlation.

The results indicate that even after taking into account the effect of various control variables, community heterogeneity is significantly negatively related to social capital. When the number of parties within a municipality is higher, thereby indicating the presence of more politically relevant socio-economic cleavages and a more heterogeneous population, the level of social capital is lower, ceteris paribus. ${ }^{7}$ The coefficient is statistically highly significant and robust over all estimations-independent of whether we use the actual or effective number of parties. ${ }^{8}$ Hence, we show that the relation between population heterogeneity and social capital found in previous research at the macro-level (e.g. Knack and Keefer 1997; Hero 1998, 2003; Coffé and Geys 2006) extends beyond specific indices of socio-economic diversity such as ethnic heterogeneity and income inequality. Moreover, our findings illustrate that the negative relation between community heterogeneity and social capital is not limited to cross-country and regional analyses, but also holds at lower levels of aggregation (namely municipalities). This strengthens the conclusions with respect to the relation between community heterogeneity and social capital.

Switching to the control variables, it can be seen that most of these are significantly related to the level of social capital in the Flemish municipalities. Firstly, and in line with the findings of Oliver (1999), we find that lower average income is associated with higher levels of social capital. This, however, contrasts with individual-level research where it has been found that high-income individuals have higher levels of social capital (Delhey and Newton 2004; Leigh 2006a, b). This illustrates that individual-level findings do not necessarily transfer to the aggregate level, nor vice versa. A similar conclusion holds for unemployment. While Hooghe (2003) finds that the unemployed in Belgium participate at significantly lower levels, our analysis indicates that the relation-though also negativeis only weakly significant at the aggregate level.

The coefficient for the share of highly educated individuals is not statistically significant while the share of elderly (over age 65) in the population shows a significant negative association with a municipality's level of social capital. Though the latter finding contrasts with Putnam's (2000) conclusion that older people tend to have a higher level of social capital, it is in line with individual-level research by Breda et al. (2003). They find that the elderly in Flanders are more often subject to feelings of insecurity and social exclusion, leading to lower levels of social capital among the elderly.

Population size as well as population concentration are negatively associated with the level of social capital in the municipality, as expected. Finally, we find that the residential stability of the population is strongly related to social capital. Both the negative effect of in- and outward migration and the positive effect of homeownership indicate that increased residential stability is associated with higher social capital. Moreover, given the statistical significance of the coefficient of homeownership over and above the effect of population

\footnotetext{
7 When the analysis is repeated for the different components of social capital separately, we find that community heterogeneity is significantly negatively correlated with electoral turnout and the number of associations within a municipality, but is not significantly correlated with the level of crime.

${ }^{8}$ Inclusion of dummy variables for four of the five Flemish provinces as a proxy for possible historicalgeographical effects does not affect this result. These dummies indicate that —all else being equal—social capital is significantly lower in the province of Antwerp relative to the other provinces.
} 
mobility, possession of a house appears to create an additional incentive to invest in social capital (due to one's financial investment in the community).

\subsection{Robustness Analysis}

As mentioned before, the number of parties competing in the election is likely to be affected by the characteristics of the electoral system. More proportional systems tend to lower both the psychological and mechanical hurdle for (small) groups to compete in elections (Duverger 1954). As all Belgian municipalities use the same electoral system (see above), the proportionality of the vote-seat distribution is only affected by the variation in the district magnitude (i.e. the number of seats in the local council). This varies between 7 and 55 seats. To the extent that municipalities with a higher DM have more parties, the number of parties in the election may be measuring more than just community heterogeneity. This would obviously undermine the validity of party system fragmentation as a proxy for community heterogeneity.

To check whether the variation in DM across Flemish municipalities-and its effect on party system fragmentation-affects our results, we split our sample into three groups with little variation in the number of seats in the council. The argument is that within these groups the DM has only a very marginal effect on the number of parties, leaving us with an uncontaminated proxy for socio-economic diversity. Specifically, we re-estimate the model for municipalities with a DM of 13 to 19 seats (78 observations), 21 to 25 seats (148 observations) and 27 to 33 seats (61 observations). ${ }^{9}$

Prior to discussing the results, it is important to point out that grouping municipalities with respect to the number of seats on their council tends to increase the correlations between the variables in the model. This significantly enhances the possibility of multicollinearity in our explanatory variables. To alleviate the problems of excessive multicollinearity, we started out from the full model - as presented in Table 2-for each of the three groups, but eliminated non-significant variables one by one from the model in subsequent estimations. The coefficients reported in Table 3 are from the estimation with highest adjusted $R^{2}$.

Due to space restrictions, we only report the results when using OLS estimations (though the interval regression technique leads to comparable results; available upon request). For each set of results, the first column (i.e. (1) and (4)) shows the findings for the group of municipalities with a DM between 13 and 19 seats, the second column (i.e. (2) and (5)) for those with 21-25 seats in the council and the third column (i.e. (3) and (6)) for the municipalities with a DM between 27 and 33 seats.

The results in Table 3 indicate that the relation between community heterogeneity and social capital becomes somewhat weaker but remains statistically significant in all estimations. This holds for both the actual and the effective number of parties in the election and thus substantiates the results reported in Table 2. We also repeated the analysis on subsamples where the DM did not vary (available upon request). For six DM sizes (i.e. 17, $19,21,23,25$ and 27 seats), the number of observations was sufficient to perform meaningful empirical tests (namely between 23 and 60 observations). Five results were in the expected (negative) direction. Four of these were statistically significant at better than the five per cent level, while one more was significant only at the $20 \%$ level. For

\footnotetext{
${ }^{9}$ In the selection of these groups, we balanced the need to have sufficient observations to perform meaningful regression analyses with the desire to minimize variation in the DM within the groups. Note that these criteria lead us to exclude 18 municipalities with very high or very low DM.
} 
Table 3 Robustness analyses (OLS results)

\begin{tabular}{|c|c|c|c|c|c|c|}
\hline Variables & $\begin{array}{l}\text { (1) DM } \\
(13-19)\end{array}$ & $\begin{array}{l}\text { (2) DM } \\
(21-25)\end{array}$ & $\begin{array}{l}\text { (3) } \mathrm{DM} \\
(27-33)\end{array}$ & $\begin{array}{l}\text { (4) DM } \\
(13-19)\end{array}$ & $\begin{array}{l}\text { (3) DM } \\
(21-25)\end{array}$ & $\begin{array}{l}\text { (4) DM } \\
(27-33)\end{array}$ \\
\hline Intercept & $\begin{array}{c}5.189 * * * \\
(3.95)\end{array}$ & $\begin{array}{r}5.593 * * \\
(2.23)\end{array}$ & $\begin{array}{l}2.382 * \\
\quad(1.71)\end{array}$ & $\begin{array}{c}4.808 * * * \\
(3.66)\end{array}$ & $\begin{array}{r}6.016^{* * *} \\
(2.50)\end{array}$ & $\begin{array}{r}6.387 * \\
(1.69)\end{array}$ \\
\hline INC & $\begin{array}{l}-0.134 \\
(-1.54)\end{array}$ & $\begin{array}{c}-0.124 * * * \\
(-3.00)\end{array}$ & - & $\begin{array}{r}-0.165^{*} \\
(-1.93)\end{array}$ & $\begin{array}{r}-0.096 * * \\
(-2.48)\end{array}$ & - \\
\hline EDUC & $\begin{array}{r}-0.051^{*} \\
(-1.84)\end{array}$ & - & - & $\begin{array}{l}-0.042 \\
\quad(-1.51)\end{array}$ & - & - \\
\hline UNEM & $\begin{array}{c}-0.517 * * * \\
(-4.33)\end{array}$ & $\begin{array}{l}-0.098 \\
(-1.21)\end{array}$ & $\begin{array}{l}-0.103 \\
\quad(-1.36)\end{array}$ & $\begin{array}{c}-0.500 * * * \\
(-4.17)\end{array}$ & - & $\begin{array}{l}-0.085 \\
\quad(-1.12)\end{array}$ \\
\hline AGE & $\begin{array}{c}-0.112 * * * \\
(-3.38)\end{array}$ & $\begin{array}{c}-0.084 * * * \\
(-3.57)\end{array}$ & $\begin{array}{c}-0.128 * * * \\
(-4.17)\end{array}$ & $\begin{array}{c}-0.110 * * * \\
(-3.29)\end{array}$ & $\begin{array}{c}-0.076 * * * \\
(-3.37)\end{array}$ & $\begin{array}{r}-0.132 * * * \\
(-4.29)\end{array}$ \\
\hline $\begin{array}{l}\text { POP } \\
\quad(\ln )\end{array}$ & - & $\begin{array}{r}-0.485^{* *} \\
(-2.05)\end{array}$ & - & - & $\begin{array}{c}-0.606 * * * \\
(-2.77)\end{array}$ & $\begin{array}{r}-0.387 \\
\quad(-1.16)\end{array}$ \\
\hline CONC & $\begin{array}{r}-0.001^{*} \\
(-1.80)\end{array}$ & - & - & $\begin{array}{r}-0.0004 \\
(-1.46)\end{array}$ & - & - \\
\hline MIGR & $\begin{array}{l}-0.007 \\
(-1.17)\end{array}$ & $\begin{array}{c}-0.010 * * * \\
(-3.61)\end{array}$ & $\begin{array}{c}-0.015 * * * \\
(-4.63)\end{array}$ & $\begin{array}{l}-0.007 \\
(-1.18)\end{array}$ & $\begin{array}{c}-0.010 * * * \\
(-3.82)\end{array}$ & $\begin{array}{c}-0.014 * * * \\
(-4.21)\end{array}$ \\
\hline HOME & $\begin{array}{l}0.021 \\
\quad(1.66)\end{array}$ & $\begin{array}{c}0.040 * * * \\
(4.14)\end{array}$ & $\begin{array}{l}0.018 \\
\quad(1.38)\end{array}$ & $\begin{array}{r}0.027 * * \\
(2.00)\end{array}$ & $\begin{array}{c}0.043 * * * \\
(4.58)\end{array}$ & $\begin{array}{l}0.016 \\
\quad(1.30)\end{array}$ \\
\hline $\begin{array}{l}\text { Actual number } \\
\text { parties }\end{array}$ & $\begin{array}{r}-0.155^{* *} \\
(-2.24)\end{array}$ & $\begin{array}{r}-0.085^{* *} \\
(-2.58)\end{array}$ & $\begin{array}{r}-0.089 * * \\
(-2.20)\end{array}$ & - & - & - \\
\hline $\begin{array}{l}\text { Effective number } \\
\text { parties }\end{array}$ & - & - & - & $\begin{array}{r}-0.190 * * \\
(-2.00)\end{array}$ & $\begin{array}{c}-0.146 * * * \\
(-3.11)\end{array}$ & $\begin{array}{r}-0.160 * * * \\
(-2.26)\end{array}$ \\
\hline$N$ & 78 & 148 & 61 & 78 & 148 & 61 \\
\hline$R^{2}$ adj & 57.64 & 58.30 & 60.19 & 56.80 & 58.99 & 60.86 \\
\hline
\end{tabular}

Note: Unstandardised regression coefficients; $t$-values in brackets; $* * *$ significant at $1 \%$, ** at $5 \%$ and $*$ at $10 \%$

municipalities with a DM equal to 23 , we obtained a positive, though insignificant result. These findings - though at times obtained from admittedly rather small samples-thus support our main conclusions. ${ }^{10}$ A higher level of party system fragmentation-indicating a more heterogeneous population-is strongly negatively associated with the level of social capital in the municipality, ceteris paribus.

\section{Conclusion}

In recent years, a rapidly growing body of research has reported on the beneficial nature of social capital. Although this view of social capital as a normatively positive force has been heavily criticised from a theoretical point of view (see e.g. Foley and Edwards 1998; DeFilippis 2001; Casey 2004), it has also provoked the question what factors promote (or block) its emergence. For one thing, the socio-economic context of the community may have an important role to play. Indeed, different societal environments imply varying

\footnotetext{
${ }^{10}$ Finally, including DM as an explanatory variable in the full model in Table 2 does not affect our results (despite obvious multicollinearity problems given that the district magnitude in Belgian municipalities is by federal law determined as a direct function of population size).
} 
limitations or possibilities with respect to the development of associations, bonds of solidarity and generalized trust.

In this article, we focused on the relation between community heterogeneity and social capital. Though several previous studies have found a significant negative relation between community heterogeneity and social capital, these analyses have been confined to mostly cross-country or regional-level comparisons and to specific measures of heterogeneity (predominantly income inequality and ethnic diversity). We extended these previous studies by using data at a lower level of government (i.e. Flemish municipalities) and by introducing a more general measure of community heterogeneity (i.e. party system fragmentation). Indeed, given that the level of party system fragmentation is dependent on the number of socio-economic cleavages in the electorate, it taps into various sources of heterogeneity and thus has the advantage over the previous indices to be more encompassing.

Our results show that the level of social capital in Flemish municipalities is significantly and negatively related to the number of parties in the local party system. This is consistent with previously obtained results and indicates that these can be generalized to lower levels of aggregation and broader measures of heterogeneity.

Acknowledgement The author wishes to thank Benny Geys for helpful discussions.

Open Access This article is distributed under the terms of the Creative Commons Attribution Noncommercial License which permits any noncommercial use, distribution, and reproduction in any medium, provided the original author(s) and source are credited.

\section{Appendix: Summary statistics}

\begin{tabular}{llrccc}
\hline Variables & Symbol & \multicolumn{1}{c}{ Mean } & Standard deviation & Minimum & Maximum \\
\hline Social capital & SOCKAP & -0.004 & 0.999 & -3.354 & 3.358 \\
Income & INC & 10.710 & 1.394 & 7.234 & 15.498 \\
Education & EDUC & 14.006 & 4.218 & 6.069 & 32.772 \\
Unemployment & UNEM & 2.064 & 0.809 & 0.809 & 5.923 \\
Elderly & AGE & 15.916 & 2.479 & 8.535 & 24.109 \\
Population size (ln) & POP (ln) & 9.549 & 0.709 & 6.884 & 13.012 \\
Population concentration & CONC & 511.890 & 443.754 & 51 & 3138 \\
Population mobility & MIGR & 8.252 & 2.194 & 2.450 & 18.300 \\
Homeownership & HOME & 74.987 & 7.968 & 46 & 92 \\
Actual number of parties & & 5.482 & 2.271 & 2 & 18 \\
Effective number of parties & & 3.468 & 1.105 & 1.450 & 7.943 \\
\hline
\end{tabular}

\section{References}

Abrams, D., Hogg, M. A., \& Marques, J. M. (2005). The social psychology of inclusion and exclusion. New York: Psychology Press.

Alesina, A., \& La Ferrara, E. (2000). Participation in heterogeneous communities. Quarterly Journal of Economics, 115(3), 847-904. 
Bjørnskov, C. (2003). Corruption and social capital. Aarhus School of Business Working Paper no 03-13. Blalock, H. M. (1967). Towards a theory of minority-group relations. New York: Wiley.

Bloso (2004). Bevraging van de gemeentelijke sportdiensten naar de gemeentelijke subsidiëring van de sportclubs. Brussels: Bloso.

Boix, C., \& Posner, D. (1998). Social capital: Explaining its origins and effects on government performance. British Journal of Political Science, 28(4), 686-695.

Bourdieux, P. (1985). The forms of capital. In J. Richardson (Ed.), Handbook of theory and research for the sociology of education (pp. 241-258). New York: Greenwood.

Bowles, S., \& Gintis, H. (2002). Social capital and community governance. The Economic Journal, 112, F419-F436.

Breda, J., Schoenmaekers, D., \& Van Geel, H. (2003). Hoe Vlamingen sociale uitsluiting percipiëren. In Ministerie van de Vlaamse Gemeenschap (Ed.), Vlaanderen gepeild! (pp. 53-97). Brussels: Ministerie van de Vlaamse Gemeenschap

Buchanan, J. (1965). Ethical rules, expected values and large numbers. Ethics, LXXVI, 1-13.

Casey, T. (2004). Social capital and regional economies in Britain. Political Studies, 52, 96-117.

Coffé, H., \& Geys, B. (2005). Social capital and institutional performance: A local-level analysis. Journal of Urban Affairs, 27(5), 485-501.

Coffé, H., \& Geys, B. (2006). Community heterogeneity: A burden for the creation of social capital? Social Science Quarterly, 87(5), 1053-1072.

Coleman, J. (1988). Social capital and the creation of human capital. Journal of Sociology, 94, S95-S120.

Costa, D. L., \& Kahn, M. E. (2003). Civic engagement and community heterogeneity: An economist's perspective. Perspectives on Politics, 1(1), 103-111.

DeFilippis, J. (2001). The myth of social capital in community development. Housing Policy Debate, 21(4), 781-806.

Delhey, J., \& Newton, K. (2004). Social trust: Global pattern or Nordic exceptionalism? Discussion paper. Berlin: WZB.

Delhey, J., \& Newton, K. (2005). Predicting cross-national levels of social trust: Global pattern of Nordic exceptionalism? European Sociological Review, 21(4), 311-327.

DiPasquale, D., \& Glaeser, E. L. (1999). Incentives and social capital: Are homeowners better citizens? Journal of Urban Economics, 45, 354-384.

Duverger, M. (1954). Political parties: Their organisation and activity in the modern state. London: Methuen.

Foley, M. W., \& Edwards, B. (1998). Beyond Toqueville: Civil society and social capital in comparative perspective. American Behavioral Scientist, 42(1), 5-20.

Freitag, M. (2006). Bowling the state back in: Political institutions and the creation of social capital. European Journal of Political Research, 45, 123-152.

Geys, B. (2004). Proportional representation, political fragmentation and political decision-making: An economic analysis. Unpublished Ph.D. Dissertation, Vrije Universiteit Brussel, Brussels.

Geys, B. (2006). District magnitude, social heterogeneity and local party system fragmentation. Party Politics, 12(2), 281-297.

Gittell, R., \& Vidal, A. (1998). Community organizing: Building social capital as a development strategy. Thousand Oaks: Sage.

Glaeser, E. L., Laibson, D. I., Scheinkman, J. A., \& Soutter, C. L. (2000). Measuring trust. Quarterly Journal of Economics, 115(3), 811-846.

Green, R. K., \& White, M. J. (1997). Measuring the benefits of homeowning: Effects on children. Journal of Urban Economics, 41, 441-461.

Halpern, D. (2005). Social capital. Cambridge: Polity Press.

Hardin, R. (1993). The street-level epistemology of trust. Politics and Society, 21, 505-529.

Hero, R. E. (1998). Faces of inequality: Social diversity in American politics. Oxford: Oxford University Press.

Hero, R. E. (2003). Social capital and racial inequality in America. Perspectives on Politics, 1(1), 113-122.

Hooghe, M. (2003). Sociaal kapitaal in Vlaanderen. Verenigingen en democratische politieke cultuur. Amsterdam: Amsterdam University Press.

Hooghe, M., \& Stolle, D. (2003). Introduction: Generating social capital. In M. Hooghe \& D. Stolle (Eds.), Generating social capital. Civil society and institutions in comparative perspective (pp. 1-18). New York: Palgrave Macmillan.

Inglehart, R. (1997). Modernization and postmodernization. Cultural, economic and political change in 43 countries. Princeton: Princeton University Press.

Jones, M. P. (1997). Racial heterogeneity and the effective number of candidates in majority runoff elections: Evidence from Louisiana. Electoral Studies, 16(3), 349-358. 
Karvonen, L., \& Kuhnle, S. (2002). Party systems and voter alignments revisited. London: Routledge.

Knack, S. (2002). Social capital and the quality of government: Evidence from the States. American Journal of Political Science, 46(4), 772-785.

Knack, S., \& Keefer, P. (1997). Does social capital have an economic payoff? A cross-country analysis. Quarterly Journal of Economics, 112(4), 1251-1288.

Kumlin, S., \& Rothstein, B. (2005). Making and breaking social capital: The impact of welfare state institutions. Comparative Political Studies, 38(4), 339-365.

Laakso, M., \& Taagepera, R. (1979). "Effective" number of parties: A measure with application to West Europe. Comparative Political Studies, 12(1), 3-27.

Lane, J.-E., \& Errson, S. O. (1987). Multipartism. In M. J. Holler (Ed.), The logic of multiparty systems (pp. 153-173). Dordrecht: Martinus Nijhoff Publishers.

La Porta, R., Lopez-de-Silanes, F., Shleifer, A., \& Vishny, R. W. (1997). Trust in large organisations. American Economic Review, 87(2), 333-338.

Lauwerysen, K., \& Colpaert, T. (2004). De lokale afdelingen van de social-culturele verenigingen in kaart gebracht. Socius Gegevens, 3, 53-71.

Leigh, A. (2006a). Does equality lead to fraternity? Economics Letters, 93(1), 121-125.

Leigh, A. (2006b). Trust, inequality and ethnic heterogeneity. Economic Record, 82(258), 268-280.

Lijphart, A. (1999). Patterns of democracy: Government forms and performance in 36 countries. New Haven: Yale University Press.

Lipset, S. M., \& Rokkan, S. (1967). Party systems and voter alignments: Cross-national perspectives. New York: The Free Press.

Maloney, W., Smith, G., \& Stoker, G. (2000). Social capital and urban governance: Adding a more contextualized 'top-down' perspective. Political Studies, 48, 802-820.

Marshall, M., \& Stolle, D. (2004). Race and the city: Neighborhood context and the development of generalized trust. Political Behavior, 26(2), 125-153.

McFadden, D. (1974). The measurement of urban travel demand. Journal of Public Economics, 25, 303-328.

Meltzer, A. H., \& Richard, S. F. (1981). A rational theory of the size of government. Journal of Political Economy, 89, 914-927.

Misztal, B. (1995). Trust in modern societies. Cambridge: Polity Press.

Newton, K. (1999). Social and political trust in established democracies. In P. Norris (Ed.), Critical citizens (pp. 169-187). New York: Oxford University Press.

Newton, K. (2001). Trust, social capital, civil society and democracy. International Political Science Review, 22, 201-204.

Oliver, E. (1999). The effects of metropolitan economic segregation on local civic participation. American Journal of Political Science, 43(1), 186-212.

Oliver, J. E., \& Mendelberg, T. (2001). Reconsidering the environmental determinants of white racial attitudes. American Journal of Political Science, 44(3), 574-598.

Ordeshook, P. C., \& Shvetsova, O. V. (1994). Ethnic heterogeneity, district magnitude and the number of parties. American Journal of Political Science, 38(1), 100-123.

Overbye, E. (1995). Making a case for the rational self-regarding 'ethical' Voter ... and solving the 'paradox of not voting' in the process. European Journal of Political Research, 27, 369-396.

Portes, A. (1998). Social capital: Its origins and applications in modern sociology. Annual Review of Sociology, 24, 1-24.

Putnam, R. (1993). Making democracy work. Civic traditions in modern Italy. Princeton: Princeton University Press.

Putnam, R. (2000). Bowling alone: Collapse and revival of American community. New York: Simon \& Schuster.

Putnam, R. (2006). E Pluribus Unum: Diversity and community in the twenty-first century. The 2006 Johan Skytte Prize Lecture. Scandinavian Political studies, 30, 137-174.

Rae, D. W., \& Taylor, M. (1970). The analysis of political cleavages. New Haven: Yale University Press.

Rice, T. W. (2001). Social capital and government performance in Iowa communities. Journal of Urban Affairs, 23(3-4), 375-389.

Rice, T. W., \& Sumberg, A. F. (1997). Civic culture and government performance in the American states. Publius: the Journal of Federalism, 27(1), 99-114.

Riker, W. H., \& Ordeshook, P. C. (1968). A theory of the calculus of voting. American Political Science Review, 62, 25-42.

Rothstein, B., \& Stolle, D. (2001). Social capital and street-level bureaucracy: An institutional theory of generalized trust. Paper presented at the ESF Conference "Social capital: Interdisciplinary perspectives”, Exeter, 15-20 September 2001. 
Rothstein, B., \& Uslaner, E. M. (2004). All for all: Equality and social trust. Working Paper, Göteborg: Göteborg University.

Sampson, R. J., Raudenbush, S. W., \& Earls, F. (1997). Neighborhoods and violent crime: a multilevel study of collective efficacy. Science, 277, 918-924.

Sartori, G. (1968). The influence of electoral systems: Faulty laws or faulty method? In B. Grofman \& A. Lijphart (Eds.), Electoral laws and their political consequences (pp. 43-68). New York: Agathon Press Inc.

Stolle, D. (1998). Bowling together, bowling alone: The development of generalized trust in voluntary associations. Political Psychology, 19, 497-525.

Stolle, D. (2000). Onderzoek naar sociaal kapitaal. Naar een attitudinale benadering. In M. Hooghe (Ed.), Sociaal kapitaal en democratie. Verenigingsleven, sociaal kapitaal en politieke cultuur (pp. 25-59). Leuven: Acco.

Stolle, D. (2003). The sources of social capital. In M. Hooghe \& D. Stolle (Eds.), Generating social capital. Civil society and institutions in comparative perspective (pp. 19-42). New York: Palgrave Macmillan.

Taagepera, R., \& Grofman, B. (1985). ethinking Duverger's law: Predicting the effective number of parties in plurality and PR systems_-parties minus issues equals one. European Journal of Political Research, 13, 341-352.

Taagepera, R., \& Shugart, W. F. (1989). Seats and votes: The effects and determinants of electoral systems. New Haven: Yale University Press.

Thomas, R. L. (1997). Modern econometrics: An introduction. Harlow: Addison-Wesley-Longman Ltd.

Verba, S., Lehman, K., \& Brady, H. (1995). Voice and inequality. Civic voluntarism in American Politics. Cambridge: Harvard University Press.

Weber, M. (1947). Wirtschaft und Gesellschaft (3rd ed.). Tübingen: J.C.B. Mohr.

Wirth, L. (1938). Urbanism as a way of life. American Journal of Sociology, 44, 3-24. 